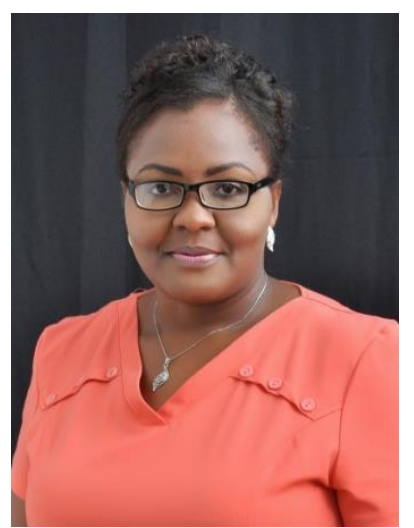

Akhere A. Omonkhua (PhD)

\title{
Announcing a New Editor, African Journal of Reproductive Health
}

To increase the functionality and impact of the African Journal of Reproductive Health (AJRH), a few organizational changes recently took place in the management of the journal. Professor Friday Okonofua, the founding editor, has now moved to the position of Editor-In-Chief, while a new editor has been appointed for the journal. The editor is Dr. Akhere Omonkhua, an associate professor of Medical Biochemistry at the University of Benin in Nigeria. Dr. Omonkhua is a renowned biochemist with deep interest in seeking to understand the scientific basis for the use of traditional medicinal plants in the treatment of diseases in Africa, including those that relate to the reproductive system. She is a strong advocate for women's health, gender equality, and social equity for women. She has demonstrated through the many positions she has held that she is deeply committed to women's empowerment and the effective participatory roles for women in high-level governance.

Dr. Omonkhua obtained a Bachelors' degree, with a Second Class Upper Division in 1998 and a Masters' Degree in 2002 (with the class prize) in Biochemistry from the University of Benin. She was awarded a $\mathrm{PhD}$ in Toxicology from the same University in 2010. Her PhD Thesis titled Toxicological and anti-diabetic evaluation of some local medicinal plants was nominated for the National Universities Commission of Nigeria Doctoral Award by the University of Benin in 2012.

Dr. Omonkhua started her career as an Assistant Lecturer at the Adekunle Ajasin University,
Akungba-Akoko and South-west Nigeria in 2003. She transferred her services to the University of Benin as Senior Lecturer in 2012; and was promoted to the rank of Associate Professor in October, 2015. Akhere is an avid researcher, with major focus on determining the efficacy and safety of anti-diabetic and antimalarial medicinal plants, as well as elucidating the phytochemicals and mechanism(s) of action of these plants. She has over 30 local, national and international journal publications. She has presented papers in several local and international conferences. Akhere is a member of the editorial board of Biokemistri, and is the Editor, Section on Biological Sciences of the Annals of Science and Technology. She is also an active member of the Nigerian Young Academy which is affiliated to the Nigerian Academy of Science.

The AJRH is very proud of this new recruitment as we are convinced that Dr. Akhere Omonkhua will bring her deep passion and considerable commitment to work and take the journal to higher levels of achievement. We congratulate her very warmly and wish her good luck in the new assignment.

Friday Okonofua, MD, PhD, FAS Editor in Chief, AJRH 


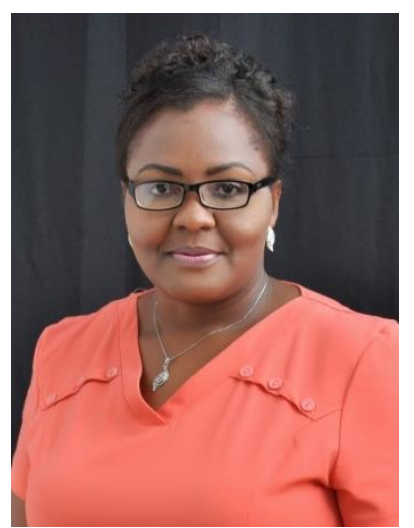

Akhere A. Omonkhua (PhD)

\section{Annonce d'un nouvelle rédactrice, Revue africaine de santé de la reproduction}

Pour accroître la fonctionnalité et l'impact de la Revue africaine de santé de la reproduction (RASR), quelques changements organisationnels se sont déroulés récemment dans la gestion de la revue. Le professeur Friday Okonofua, le rédacteur fondateur, est maintenant passé au poste de rédacteur en chef, alors qu'une nouvelle rédactrice en chef a été nommée pour la revue. La rédactrice est le Dr Akhere Omonkhua, professeur associée de biochimie médicale à l'Université de Bénin au Nigéria. Le Dr Omonkhua est une biochimiste renommée qui s'intéresse profondément à la compréhension de la base scientifique de l'utilisation des plantes médicinales traditionnelles dans le traitement des maladies en Afrique, y compris celles liées au système de la reproduction. Elle est un défenseur de la santé des femmes, de l'égalité entre les sexes et de l'équité sociale pour les femmes. Elle a démontré à travers les nombreux postes qu'elle a occupés qu'elle est profondément attachée à l'autonomisation des femmes et aux rôles participatifs efficaces pour les femmes dans la gouvernance de haut niveau. Le Dr Omonkhua a obtenu une licence, avec mention très bien en 1998 et une maîtrise en 2002 (remportant le prix pour la meilleure performance de la classe) en biochimie de l'Université de Bénin. Elle a obtenu un doctorat en toxicologie de la même université en 2010. $\mathrm{Sa}$ thèse de doctorat, intitulée «Évaluation toxicologique et antidiabétique de certaines plantes médicinales locales » a été désignée pour le Prix de doctorat de la Commission nationale des universités nigérianes par l'Université de Bénin en 2012.
Le Dr Omonkhua a commencé sa carrière en tant que conférenciere adjoint à l'Université Adekunle Ajasin, Akungba-Akoko, au sud-ouest du Nigéria en 2003. Elle a transféré ses services à l'Université de Bénin en tant que conférencière en 2012; Et a été promu au rang de professeur associé en octobre 2015. Akhere est une chercheuse avide, avec un accent majeur sur la détermination de l'efficacité et la sécurité des plantes médicinales antidiabétiques et antipaludiques, ainsi que l'élucidation des phytochimiques et des mécanismes d'action de ces plantes. Elle a publié plus de 30 articles scolaires dans des revues locales, nationales et internationales. Elle a présenté des communications dans plusieurs conférences locales et internationales. Akhere est membre du comité de rédaction de Biokemistri et est rédactrice en chef de la Section des sciences biologiques des Annales de la science et de la technologie. Elle est également membre actif de la Jeune Académie du Nigeria qui est affiliée à l'Académie nigériane des sciences.

La RASR est très fière de ce nouveau recrutement, car nous sommes convaincus que le Dr Akhere Omonkhua apportera sa passion profonde et son engagement considérable à travailler et à suivre la revue à des niveaux de réussite plus élevés. Nous la félicitons très chaleureusement et nous lui souhaitons bonne chance dans la mission.

Friday Okonofua, MD, PhD, FAS Rédacteur en chef, AJRH 